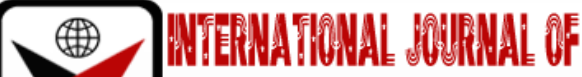

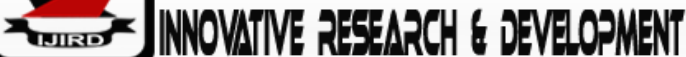

ISSN 2278-0211 (Online)

\section{Principal's Administrative Strategies and Students' Academic Performance in Public Secondary Schools in Delta North Senatorial District of Delta State, Nigeria}

\author{
Dr. Anthony Great Ossai \\ Senior Lecturer, Department of Educational Administration and Planning, \\ University of Delta, Agbor, Delta State, Nigeria
}

\begin{abstract}
:
This study examined the relationship between principals' administrative strategies and students' academic performance in public secondary schools in Delta North Senatorial District of Delta State. The study adopted a descriptive research design of the survey and ex-post facto types. The simple random sampling technique was used to select twenty (20) secondary school. In each of the school, ten (10) teachers were selected and on a whole, 200 teachers from 20 public secondary schools were used to elicit relevant data for the study. A questionnaire titled 'Principals' and Administrative Strategies Questionnaire (PASQ) was used to elicit relevant data for the study. To ascertain the validity of the instrument, the content validity was adopted. Also, the reliability co-efficient of the instrument was obtained through test-re-test method and the reliability co-efficient of 0.65 was obtained. One research question and four hypotheses were formulated to guide the study; thus, the simple percentage was used to test the research question while the Pearson product moment correlation statistics was used to test the four hypotheses at 0.05 level of significance. The findings showed that there was significant relationship between Principals administrative strategies and students' academic performance. These strategies include motivation of teachers, delegation of authority, monitoring instruction etc. The study recommended among others that there should be regular staff meeting and collective decision making and ensure that teachers teach what is in the syllabus.
\end{abstract}

Keywords: Principals, administrative strategy, students, academic performance

\section{Introduction}

Education is seen as the backbone of development of any nation, it improves the quality of life of a society through the refinement of its potential educationwhich further enhances the application of man's achievement towards improvement of his environment. Today, there is an increasing faith in the casual relationship between education and economic development especially in the developing countries like Nigeria. Education has been seen as a vehicle for economic, social-cultural and political development of nations and individuals ${ }^{1}$. Education is a social process in which one achieves societal competence and individual growth. Education is the art of learning above one-self, and one's environment for the purpose of self-development.

Education is a tool for building a united, independent, wealthy and egalitarian society that can maintain its tradition and values. The secondary system is however a very crucial level of educational system. It is a gateway to the tertiary education and a ripe age for developing students' potentials. Its benefits should be commensurate with the cost, for this reason, the performance at this level is of significant importance to educational planners and managers. The school as a formal organization is the center for all teaching and learning processes. The principals and teachers as human resources are sine qua non in goal achievement of the school instructional leadership, pupil's relationship, academic achievement of the students, manipulation of facilities and other areas of teaching task must be performed at the school building and within the community level.

The quest for improved academic performance of students necessitated the ability of principals to demonstrate or use certain administrative strategies to ensure a complete well-round education and production of quality students from the secondary school system. The government, parents, and other stake holders in education expect principals to work effectively for the enhancement of students' academic performance. Principals, as schools' chief executives, are charged with the daunting task of managing the school for effectiveness. Towards this end, Lydiah and Nasongo, were of the view that students' academic performance depends on effective leadership².

There are many strategies that could be employed by principals in order to have a grip of the whole school and consequently move the school forward academically. These range from the monitoring of teachers' activities, use of committee system in schools, performance appraisal, participatory decision making, delegation of duties and regular staff meeting. 
Moreover, there appears to be poor monitoring of teachers' activities, with poor performance appraisal of teachers, which often result in poor instructional delivery in schools. For instance, Ayeni\&Akinfolarin noted that to improve students' academic performance, principals are required to improve the administrative strategies in schools ${ }^{3}$. This can be done by setting a clear vision for the school, adequate job analysis and work plan, regular staff meeting, delegation of authority, effective monitoring of teachers and non-teaching staff, involvement of teachers in decision making and committee system. Although principals have been providing leadership in the school system to some extent, but some administrative strategies that could lead to the achievement of school objectives are lacking.

The use of a set of administrative strategies by principals is informed by the fact that principals are to bring all round development into the school, in order to improve students' academic performance. They must be able to adopt some administrative strategies and also evaluate their teachers in order to ascertain the strengths and weakness of the instructional delivery system for optimal academic performance. However, gaps in the principals' Administrative strategies will no doubt cause set-back in teaching and learning process. Thus, the study investigated principal's leadership and administrative effectiveness in secondary schools in Delta North Senatorial District of Delta State.

\subsection{Statement of the Problem}

The present and future implications of the academic performance of students in the senior school certificate examination (SSCE) has been a source of worry to the public and stakeholders in the education sector. Also, there is a growing concern of the society about the realization of secondary education objectives due to the observation that some principals do not use some administrative strategies that could facilitate better performance of students in public examinations is indicative of the fact that secondary education in Nigeria has fallen drastically ${ }^{4}$. For example, the poor performance of students in SSCE and NECO exams registered an average failure rate of 72percent, 74 percent, 74 percent and 75 percent in 2005, 2009, 2009, 2010 and 2011 respectively(5). Less than 30 percent of over a million students who sat for the examination within the last six years obtained credits in five subjects including English Language and Mathematics. Ayodele believes that the falling level of academic performance is attributable to principal's non-use of verbal reinforcement strategy ${ }^{6}$. The attitude of some teachers to their job is reflected in their poor attendance to their lessons, lateness to school, unsavory comments about student's ability that could damage their ego, poor method of teaching and the likes affected students' academic performance.

Observation in the secondary school system shows that the leadership/administrative strategies of principals could have a serious impact on the performance of students in public examinations. Therefore, the problem investigated was how leadership strategies and administrative effectiveness impacted on students' academic performance in secondary schools in Delta North senatorial District of Delta State.

\subsection{Purpose of the Study}

The poor performance of students in external examination could be largely attributed to poor administrative strategies of principals. Thus, the purpose of the study is to examine the relationship between Principals administrative strategies and students' academic performance. This study will examine the extent by which the principals have been using motivation, participatory decision making, delegation of authority, monitoring of teachers' activities and performance appraisal as administrative strategies in Delta North Senatorial District of Delta State, Nigeria.

\subsection{Research Question}

The following research question was raised to guide the study.

1. To what extent have the principals been using the identified administrative strategies in enhancing students' academic performances.

\subsection{Research Hypotheses}

These research hypotheses were formulated to guide the study

- There is no significant relationship between principals' use of motivation strategy and students' academic performance in public secondary schools in Delta North Senatorial District of Delta State, Nigeria.

- There is no significant relationship between principals' use of participatory strategy making and students' academic performance in public secondary schools in Delta North Senatorial District of Delta State, Nigeria.

- There is no significant relationship between principals' use of delegation of authority strategy and students' academic performance in public secondary schools in Delta North Senatorial District of Delta State, Nigeria.

- There is no significant relationship between principals' use of monitoring of instruction strategies and academic performance of students in public secondary schools in Delta North Senatorial District of Delta State, Nigeria.

\section{Methodology}

The study adopted the descriptive research design of the survey and ex-post facto types. The target population comprised of all the teachers in public secondary schools in Delta North Senatorial District of Delta State, Nigeria.

Twenty secondary schools were sampled for the study and in each of the schools, 10 teachers were selected by means of simple random sampling technique, on the whole 200 teachers were selected for the study.

The instrument used for collection of data for this study is the questionnaire. The questionnaire is divided into part ' $A$ ' and ' $B$ '. part A contained demographic information about the teacher, such as the age, sex, marital status, teaching experience etc. while part ' $\mathrm{B}$ ' comprises of 16 items. The instrument was validated using content validity while the reliability co-efficient of 0.65 was obtained through test-re-test method. 
The simple percentage was used to test the research question while the Pearson Product moment correlation co-efficient was used to test the hypothesis.

\subsection{Presentation of Results}

The result for the study was obtained from the research question answered and hypothesis tested through data collected and analysed.

- Research Question 1: To what extent have the principals been using the identified administrative strategies in enhancing students' academic performances?

\begin{tabular}{|c|c|c|c|c|c|}
\hline $\mathbf{S} / \mathbf{N}$ & Administrative Strategies & Regularly & Rarely & Never & Decision \\
\hline 1 & Motivation of teachers & $\begin{array}{c}90 \\
(45)\end{array}$ & $\begin{array}{c}70 \\
(35)\end{array}$ & $\begin{array}{c}40 \\
(20)\end{array}$ & \\
\hline 2 & $\begin{array}{c}\text { Participatory decision } \\
\text { making }\end{array}$ & $\begin{array}{c}83 \\
(41.5)\end{array}$ & $\begin{array}{c}73 \\
(36.5)\end{array}$ & $\begin{array}{c}44 \\
(22)\end{array}$ & \\
\hline 3 & Delegation of authority & $\begin{array}{c}90 \\
(45)\end{array}$ & $\begin{array}{c}67 \\
(28.5)\end{array}$ & $\begin{array}{c}58 \\
(26.5)\end{array}$ & \\
\hline 4 & Monitoring of instruction & $\begin{array}{c}91 \\
(46)\end{array}$ & $\begin{array}{c}58 \\
(29)\end{array}$ & $\begin{array}{c}50 \\
(25) \\
\end{array}$ & \\
\hline
\end{tabular}

Table 1: The Extent of Utilization of Principals' Administrative Strategies

Tale 1 shows that most of the respondents (over 70\%) adjudged that the school principals regularly use the identified administrative strategies.

- Hypothesis 1: There is no significant relationship between principals' use of motivation strategy and students' academic performance in public secondary schools in Delta North Senatorial District of Delta State.

\begin{tabular}{|c|c|c|c|c|c|c|c|}
\hline Variable & N & X & SD & DF & Cal. Value & $\begin{array}{c}\text { Critical } \\
\text { Value }\end{array}$ & Decision \\
\hline $\begin{array}{c}\text { Motivation } \\
\text { Strategy }\end{array}$ & 200 & 98.6 & 21.4 & 198 & 0.246 & 0.148 & Rejected \\
\hline $\begin{array}{c}\text { Students' } \\
\text { academic } \\
\text { performance }\end{array}$ & 200 & 64.3 & 14.8 & & & & \\
\hline
\end{tabular}

Table 2: Analysis of the Significant Relationship between Principal's Use of Motivation Strategies and Academic Performance of Students

As indicated in table 2 above, the r-calculated value is 0.246 while the r-critical (table value) is 0.148 . therefore, since the r-calculated value of 0.246 is greater than the table value of 0.148 at 0.05 level of significance and 198 degrees of freedom, the null hypothesis is hereby rejected. There is a significant difference between principals use of motivation strategy and academic performance of students.

- Hypothesis 2: There is no significant relationship between principals' use of participatory decision-making strategy and students' academic performance in public secondary schools in Delta North Senatorial District of Delta State.

\begin{tabular}{|c|c|c|c|c|c|c|c|}
\hline Variable & N & X & SD & DF & Cal. Value & $\begin{array}{c}\text { Critical } \\
\text { Value }\end{array}$ & Decision \\
\hline $\begin{array}{c}\text { Motivation } \\
\text { Strategy }\end{array}$ & 200 & 84.3 & 21.8 & 198 & 0.214 & 0.148 & Rejected \\
\hline $\begin{array}{c}\text { Students' } \\
\text { academic } \\
\text { performance }\end{array}$ & 200 & 62.6 & 93 & & & & \\
\hline
\end{tabular}

Table 3: Analysis of the Significant Relationship between Principals Use of Participatory Decision-Making Strategy and Students' Academic Performance

As indicated in table 3 above, the $r$-calculated value is 0.214 while the r-critical (table value) is 0.148 . Therefore, since the r-calculated value of 0.214 is greater than the table value of 0.148 at 0.05 level of significance and 198 degrees of freedom. Hence, the null hypothesis is hereby rejected. Thus, there is a significant difference between principals use of participatory decision-making strategy and academic performance of students.

- Hypothesis 3: There is no significant relationship between principals' use of delegation of authority strategy and students' academic performance in public secondary schools in Delta North Senatorial District of Delta State. 


\begin{tabular}{|c|c|c|c|c|c|c|c|}
\hline Variable & N & X & SD & DF & Cal. Value & $\begin{array}{c}\text { Critical } \\
\text { Value }\end{array}$ & Decision \\
\hline $\begin{array}{c}\text { Delegation of } \\
\text { authority Strategy }\end{array}$ & 200 & 95.3 & 24.2 & 198 & 0.257 & 0.148 & Rejected \\
\hline $\begin{array}{c}\text { Students' academic } \\
\text { performance }\end{array}$ & 200 & 98.4 & 26.3 & & & & \\
\hline
\end{tabular}

Table 4: Analysis of the Significant Relationship between Principals Use of

Delegation of Authority Strategy and Students' Academic Performance

As indicated in table 3 above, the r-calculated value is 0.257 while the r-critical (table value) is 0.148 . Therefore, since the r-calculated value of 0.257 is greater than the table value of 0.148 at 0.05 level of significance and 198 degrees of freedom. Hence, the null hypothesis is hereby rejected. Thus, there is a significant difference between principal's use of delegation of authority strategy and academic performance of students.

- Hypothesis 4: There is no significant relationship between principals' use of monitoring of instruction strategies and academic performance of students in public secondary schools in Delta North Senatorial District of Delta State, Nigeria.

\begin{tabular}{|c|c|c|c|c|c|c|c|}
\hline Variable & $\mathbf{N}$ & $\mathbf{X}$ & SD & DF & Cal. Value & Critical Value & Decision \\
\hline $\begin{array}{c}\text { Monitoring of } \\
\text { Instruction } \\
\text { Strategy }\end{array}$ & 200 & 83.2 & 24.3 & 198 & 0.240 & 0.148 & Rejected \\
\hline $\begin{array}{c}\text { Students' } \\
\text { academic } \\
\text { performance }\end{array}$ & 200 & 92.7 & 36.2 & & & & \\
\hline
\end{tabular}

Table 5: Analysis of the Significant Relationship between Principals Use of Monitoring of Instruction Strategies and Students' Academic Performance

From table 4 above, the r-calculated value is 0.240 while the r-critical (table value) is 0.148 . therefore, since the $r$ calculated value of 0.240 is greater than the table value of 0.148 at 0.05 level of significance and of 198 degrees of freedom. Hence, the null hypothesis is hereby rejected. Thus, there is a significant difference between principals use of monitoring of instruction strategy and academic performance of students.

\section{Discussion of Results}

Research question one revealed that principals regularly use the identified administrative strategies to enhance the students' academic performance. This implies that the type of skills, techniques demonstrated by a principal in a school plays an important role in the academic performance of students. This is in consonance with the findings of earlier researchers (7)

Hypothesis one was rejected. This means that there is a significant relationship between principals use of motivational strategies and students' academic performance in schools. It is therefore imperative for secondary school principals to be acquainted with the required motivational strategies in order to perform their administrative duties. This is in agreement with Alani who asserted that principals need to possess adequate and sound managerial skills to be able to achieve administrative effectiveness. (8)

Hypothesis two was also rejected, this means that involving all stakeholders in the school system in taking decision will enable principals to do the right thing at the right time. The principals they make use of the participatory decision strategy to ensure good structure in the school for the enhancement of the academic performance of students.

Equally, hypothesis three was rejected. By implication, there is a positive relationship between principals use of delegation of authority and students' academic performance. A principal cannot be everywhere in the school system. He has to delegate responsibilities to both teachers and students. A good principal must ensure free flow of information among the personnel in the school system. No wonder Morgan (9), lamented that possibly the most vital and fundamental element in the management process is based on working with people.

Hypothesis four was also rejected. This means that there is a significant relationship between principals use of supervision of instruction strategy and students' academic performance in secondary schools. This follows that supervision of instruction plays an important role in the academic performance of students. No wonder Oyedeji, posited that of all the major functions of the school principals, no one is greater than their functions of supervision, instruction and curriculum planning (10). This finding is in agreement with the view of Ogunsanju, who opined that supervision brings about excellence and quality and it helps to give concrete and constructive advice and encourage both teachers and students in order to improve teaching and learning (11).

\section{Conclusion}

The study examined the relationship between principals' administrative strategies and students' academic performance. These strategies include motivation, delegation of authority, participatory decision making and monitoring of instruction. The study established that there is a significant relationship between the principals use of identified strategies and students' academic performance. The school principal must accept the responsibility throughout his/her 
career to use the identified strategies in order to ensure good academic performance in his/her internal and external examinations.

\section{Recommendations}

In the light of the findings of this study, the researchers hereby recommend as follows:

- Principals must endeavour to keep a light level of professional spirit and good moral level of the school. Principals of secondary school should learn how to adapt their administrative strategies to school situation in order to attain and sustain good working environment for teachers and other staff in the school.

- To be effective administrators, school principals should be involved in seminars and workshops on issues of management in education in order to enhance their administrative effectiveness by acquiring new techniques (strategies) for teacher's motivation and productivity.

- Regular supervision of teachers by supervisors and principals should be carried out to develop teachers' skills in both curricular and co-curricular activities.

- Principals should ensure that teachers teach what is in the syllabus, moderate examination questions and progress report of the school should be taken to the Ministry of Education to encourage hardworking teachers as regards promotion.

- $\quad$ There should be regular staff meeting and collective decision making, this will enable the teachers and other staff have a sense of belonging.

\section{Limitations of the Study}

Some of the issues encountered in this study include the following:

- The study is limited due to financial constraints that prevented the researcher from visiting all the schools in the senatorial district.

- The use of questionnaire in the collection of information is usually faced with several issues' distortion of facts, faking and interpretation of the objectives of the questionnaire and the study in general.

- The sample size appears too small to make assumption on all the secondary schools in Nigeria. Therefore, it becomes difficult to generalize the findings of this study.

\section{References}

i. Obayan, P.A. Revitalizing Education in Africa. Ibadan: StrilingHorden Publishers, Nigeria (2006).

ii. Lydiah, L. M \&Nasongo, J.W. Role of the head teacher in academic achievement in secondary schools in Vihia district, Kenya. Current Research. Journal of Social Sciences. 1 (3); 84 - 92 (2009)

iii. Ayeni, A. J. \&Akinfolarin, C. A. Assessing Principals' Coordinating and controlling strategies for effective Teaching and Quality Learning Outcome in secondary schools in Ondo State, Nigeria. International Journal of Learning, Teaching and Educational Research. 7 (1); 180 - 200 (2014)

iv. Baldoni, J. Great Communication Secrets of Great Leaders, New York: MC Graw-Hill. (2003)

v. Owadie, I. West African Senior School Certificate Examination Results. The Punch, p. 8. (2012)

vi. Ayodele, J.B, Buari, R.O \&Oguntuase, D.M, Principals Administrative Strategies and Students Academic Performance in Nigerian Secondary Schools, Imperial Journal of Interdisciplinary Research (IJIR) Vol 2 (1), 271277 (2016)

vii. Ayeni, A. J. Teachers' Instructional Task performance and principals' supervisory roles as correlates of quality assurance in secondary schools in Ondo State. Unpublished Doctoral dissertation, ObafemiAwolowo University, Ile-Ife, Nigeria. (2010)

viii. Alani, R.A, Introduction to Education Planning, Administration and Supervision. Lagos: Samrol Publishers (2003)

ix. Morgan, J.F. Principles of Administration and Supervision Management. New Jersey: Prentice Hall. (2002)

x. Oyedeji, N.B, Management in Education Principles and Practice. Lagos: Aras Publishers. (1998)

xi. Ogunsanju, S, The Craft of Educational Management. Illorin: Haytco Publishers (2000) 